\title{
Analisis efektivitas penerimaan pajak hiburan di Kota Jambi periode 2010-2016
}

\author{
M.Ramadhan Pahlevi*; Hardiani; Erni Achmad \\ Prodi Ekonomi Pembagunan, Fak. Ekonomi dan Bisnis,Universitas Jambi \\ E-mail korespondensi: ramadhanpahlevi64@gmail.com
}

\begin{abstract}
The purpose of this study is to determine and analyze the amount of effectiveness of entertainment tax revenue in Jambi City, to analyze the contribution of entertainment tax to local taxes in Jambi City. The data used is to look at the PAD, especially entertainment tax data which can be taken from the Jambi City Regional Income Tax Office (DISPENDA). Based on the results of the discussion on the effectiveness analysis of the entertainment tax in the city of Jambi, the period 20102-2016 shows that the development of entertainment tax in Jambi City continues. experiencing changes every year. In 2010 amounted to $6.14 \%$ from the previous year, the smallest development in 2011 was $6.14 \%$ and the largest in 2012 was 66.45\%. This research implies that the development of entertainment tax in Jambi City in the 2010-2016 period has an average development of $25.065 \%$ of each year. This entertainment tax can be increased again by providing guidance and counseling activities by related parties to owners or managers of entertainment venues in Jambi City to be active in making tax payments and further improving services.
\end{abstract}

Keywords: Effectiveness, Entertainment tax

\begin{abstract}
Abstrak
Adapun tujuan penelitian ini adalah untuk mengetahui dan menganalisis besaran efektivitas penerimaan pajak hiburan di Kota Jambi,untuk menganalisis kontribusi pajak hiburan terhadap pajak daerah di Kota Jambi. Data yang digunakan adalah dengan melihat PAD terkhususnya data pajak hiburan yang dapat diambil dari Dinas Pendapata Daerah (DISPENDA) Kota Jambi.Berdasarkan hasil pembahasan mengenai analisis efektivitas terhadap pajak hiburan di kota jambi periode 20102-2016 yaitu menunjukkan bahwa perkembangan pajak hiburan di Kota Jambi terus mengalami perubahan setiap tahunnya. Tahun 2010 sebesar $6,14 \%$ dari tahun sebelumnya perkembangan terkecil pada tahun 2011 6,14\% dan terbesar pada tahun 2012 sebesar 66,45\% implikasi dari penelitian ini adalah perkembangan pajak hiburan di Kota Jambi periode 2010-2016 memiliki rata-rata perkembangan sebesar $25,065 \%$ dari setiap tahunnya. Pajak hiburan ini sebenarnya masih dapat di tingkatkan lagi dengan memberikan kegiatan-kegiatan bimbingan dan penyuluhan oleh pihak terkait kepada pemeilik atau pengelola tempat hiburan di Kota Jambi untuk aktif dalam melakukan pembayaran pajak dan lebih meningkatkan pelayanan.
\end{abstract}

\section{Kata kunci : Efektivitas, Pajak hiburan}

\section{PENDAHULUAN}

Pembangunan Daerah didasarkan atas otonomi daerah dengan mengacu pada kondisi dan situasi suatu wilayah yang bersangkutan. Dengan demikian daerah tidak saja mengurus rumah tangganya sendiri tetapi juga menyelenggarakan tugas-tugas Pemerintah Pusat di daerah. Tentu saja hal ini membuat beban yang ditanggung oleh 
Pemerintah daerah tidaklah ringan, dan untuk menyelenggarakan tugas-tugas tersebut dibutuhkan sumber-sumber keuangan yang besar.

Selama periode pelaksanaan otonomi daerah, pemerintah telah menerbitkan Undang-Undang nomor 22 tahun 1999 yang kemudian diganti dengan Undang-Undang Nomor 32 Tahun 2004 dan yang terakhir dengan Undang-Undang Nomor 12 Tahun 2008 tentang Pemerintah Daerah yang mengatur tentang pelaksanaan otonomi daerah dengan pemberian kewenangan luas bagi daerah untuk mengatur sendiri daerahnya dan pasal yang berhubungan dengan otonomi daerah yaitu pasal 10 tetang penyelenggaraan urusan pemerintah daerah pasal 13 urusan wajib pemerintah provinsi, dan pasal 14 urusan wajib pemerintah kabupaten/kota. Seiring dengan ini, juga diterbitkan UndangUndang Nomor 25 Tahun 1999 yang diganti dengan Undang-Undang Nomor 33 Tahun 2004 tentang perimbangan kewenangan antara pemerintah pusat.

Pajak Hiburan merupakan salah satu pajak daerah yang sangat pontesial dimasa mendatang. Hal ini dikelilingi oleh tumbuhnya pusat-pusat perbelanjaan yang baru dan dibangunnya berbagai macam property serta berbagai usaha lainnya diberbagai sudut Kota Jambi, pembangunan berbagai fasilitas yang membutuhkan media yang tepat di bidang komersial maupun yang besifat pengenalan kepada masyarakat luas. Dilihat dari perkembangan pajak hiburan setiap tahunnya meningkat dari tahun 2010 -2016. Pada tahun 2010 pajak hiburan sebesar Rp.1.690.850.000 pada tahun 2011 meningkat sebesar Rp.2.065.500.000 atau 22,15\%. Pada tahun 2012 mengalami peningkatan sebesar Rp.3.400.582.332 atau sebesar 64,63\%. Pada tahun 2013 mengalami peningkatan sebesar Rp. 3.860.640.000 atau sebesar 13,52\%. Pada tahun 2014 mengalami peningkatan sebesar Rp.5.050.000.000 atau sebesar 30,80\% pada tahun 2015 mengalami peningkatan sebesar Rp.7.000.000.000 atau sebesar 38,61\% dan pada tahun 2016 mengalami peningkatan sebesar Rp.7.500.000.000 atau sebesar 7,14\%

Pajak Daerah menurut Kesit (2005) "adalah pungutan wajib atas orang pribadi atau badan yang dilakukan oleh pemerintah daerah tanpa imbalan langsung yang seimbang, yang dapat dipaksakan berdasarkan peraturan perundang-undangan yang berlaku, yang digunakan untuk membiayai penyelenggaraan pemerintah daerah dan pembangunan daerah".

Salah satu faktor penting untuk mengetahui kondisi ekonomi disuatu wilayah tertentu dalam suatu periode tertentu dapat ditunjukkan oleh data PDRB daerah tersebut, Apabila nilai PDRB mengalami peningkatan maka akan membawa pengaruh positif pada kenaikan penerimaan daerah. Semakin tinggi pendapatan seseorang maka akan semakin tinggi pula kemampuan seseorang untuk membayar berbagai pungutan yang ditetapkan pemerintah, sehingga semakin tinggi pula kemampuan masyarakat daerah tersebut untuk membayar pajak daerah yang digunakan untuk membiayai pengeluaran rutin dan pengeluaran pemabangunan pemerintah (Mardiasmono,2000 dalam Dini Nurmayasari)

Menurut Suparmoko (2000), ahli keuangan Daerah Indonesia mengemukakan yang dimaksud dengan penerimaan pemerintah dalam arti seluas-luasnya yaitu meliputi penerimaan pajak, penerimaan yang diperoleh dari hasil penjualan barang dan jasa yang dimiliki dan dihasilkan oleh pemerintah, pinjaman pemerintah, mencetak uang sebagainya. Keuangan Negara adalah semua kekayaan negara yang bukan semata-mata terdiri dari semua hak, juga meliputi semua kewajiban. Semua hak dan kewajiban itu baru bias dinilai dengan uang apabila dilaksanakan Basri dan Subri (2005).

Pengelompokan sumber-sumber penerimaan Negara menurut (Suparmoko :2002) adalah sebagai berikut :Pajak adalah pembayaran iuran oleh rakyat kepada pemerintah yang dapat di paksakan dengan tanpa balas jasa yang secara langsung dapat ditunjuk. Misalnya : pajak penjualan, pajak kendaraan bermotor.Retribusi adalah pembayaran dari rakyat kepada pemerintah dimana kita dapat melihat adanya hubungan antara balas jasa yang langsung di terima dengan adanya pembayaran retribusi tersebut.Misalnya : 
uang langgana air minum, uang langganan listrik, parkerSumbangan masyarakat untuk jasa-jasa yang di berikan oleh pemerintah seperti pembayaran biaya-biaya perizinan , toll atau pungutan sumbangan pada jalan raya tertentu.Denda-denda atau perampasan yang dilakukan oleh pemerintah Keuntungan dari perusahaan-perusahaan Negara adalah penerimaan yang berasal dari sumber ini merupakan penerimaan-penerimaan pemerintah dari hasil penjualan (harga) barang-barang yang di hasilkan oleh perusahaan.Hadiah dari pemerintah pusat ke pemerintah daerah maupun dari pemerintah swasta kepada pemerintah dan dapat juga terjadi dari pemerintah suatu negara kepada pemerintah negara lain. Penerimaan negara ini sifatnya adalah volunteer dengan balas jasa langsung maupun tidak langsung.Hasil dari undian negara adalah pemerintah akan mendapatkan dana yaitu perbedaan antara jumlah penerimaan dan lembaran surat undian yang dapat dijual dengan semua pengeluaran-pengeluarannya termasuk hadiah yang diberikan kepada pemenang dari undian negara tersebut.

Pencetakan uang kertas adalah karena sifat dan fungsinya, maka pemerintah memiliki kekuasaan yang tidak dimiliki oleh para individu dalam masyarakat.Oleh karenanya pemerintah juga mempunyai kekuasaan untuk mencetak uang kertas sendiri atau meminta kepada bank centrak guna memberikan pinjaman.Berdasarkan fungsinya, pajak dibedakan menjadi dua fungsi pajak, yaitu Budgeteir dan Regulated (mengatur). Funsi budgeteir merupakan pajak, sebagai sumber dana bagi pemerintah untuk membiayai pengeluaran-pengeluarannya, sedangkan fungsi regulated (mengatur) yaitu pajak sebagai alat untuk mengatur atau melaksanakan kebijakan pemerintah dalam bidang social dan ekonomi (Kuncoro:2002).

Menurut Mardiasno dalam buku Perpajakan (2001) mengatakan bahwa "pajak daerah adalah pajak yang dipungut daerah berdasarkan peraturan yang ditetapkan oleh daerah (melalui peraturan daerah) untuk kepentingan pembiayaan rumah tangga Pemerintah Daerah"

Menurut (Suparmoko:2002) konsep dan prinsip pajak pada umumnya memenuhi Smith's canons yang meliputi:Unsur keadilan (equity), pajak daerah harus adil baik secara vertikal maupun horizontal. Adil secara vertikal artinya pajak harus dikenalkan sedemikian rupa sehingga dirasakan adil diantara berbagai tingkat atau golongan pendapatan berbeda. Sedangkan adil secara horizontal artinya pajak dikenakan sedemikian rupa sehingga dirasakan adil diantara berbagai sektor yang berbeda pada tingkat dan golongan pendapatan yang sama.Unsur Kepastian (certainty), pajak daerah hendaknya dikenakan secara jelas, pasti dan tegas kepada setiap wajib pajak dalam arti bahwa dalam pemungutan pajak harus ada kepastian hokum mengenaik subjeknya, objeknya, dan waktu pembayarannya.Unsur kelayakan (convienence), wajib pajak harus dengan senang hati membayar pajak pada pemerintah karena pajak yang dibayarkan layak dan tidak memberatkan wajib pajak.Efesien (economy), pajak daerah yang dipungut tepat waktunya dan jangan sampai menciptakan biaya pemungutan yang lebih tinggi dari pada pendapatan pajak yang diterima pemerintah daerah.Unsur ketepatan (adequency), pajak daerah yang dipungut tepat waktunya dan jangan sampai memperberat anggaran pendapatan dan belanja pemerintah daerah yang bersangkutan.Pajak hiburan adalah pajak atas penyelenggara hiburan.Selain itu, pajak hiburan dapat pula diartikan sebagai pungutan daerah atas penyelenggara hiburan (Siahaan, 2005).Pemungutan di Indonesia saat ini didasarkan hukum yang jelas dan kuat sehingga harus dipatuhi oleh masyarakat dan pihak yang terkait. Dasar hukum pemungutan Pajak Hiburan pada suatu kabupaten atau kota adalah sebagaimana di bawah ini.Undang-Undang Nomor 34 Tahun 2000 yang merupakan perubahan atas Undang-Undang Nomor 18 Tahun 1997 tentang Pajak Daerah danRetribusi.

Peraturan Pemerintah Nomor 65 Tahun 2001 tentang PajakDaerah.Peraturan Daerah Kabupaten/Kota yang mengatur tentang Pajak Hiburan.keputusan bupati/walikota yang mengatur tentang Pajak Hiburan sebagai aturan pelaksana 
peraturan daerah tentang Pajak Hiburan pada kabupaten atau kota yang dimaksud (Siahaan,2005).Berdasarkan Peraturan Daerah Kota Jambi Nomor 1 Tahun 2011 Tentang Pajak Daerah Pasal 18. objek pajak hiburan adalah jasa penyelenggara hiburan dengan dipungut bayaran, yaitu tontonanfilmpagelaran kesenian, musik, tari (tari modern), dan/ataubusana.konteskecantikan, binaraga, dansejenisnyapamerandiskotik, karaoke, klab malam, dansejenisnyasirkus, akrobat, dansulappermainan bilyard, golf, bollingpacuan kuda, kendaraan bermotor, dan permainanketangkasanpanti pijat, refleksi, mandi uap/spa, dan pusat kebugaran (fitness center)pertandinganolahraga.

Pada pajak hiburan, tidak semua penyelenggara hiburan dikenakan pajak. Ada beberapa pengecualian yang tidak termasuk objek pajak, yaitu penyelenggaraan hiburan yang tidak dipungut bayaran, antara lain hiburan yang diselenggarakan dalam rangka acara pernikahan, upacara adat, kegiatan keagamaan, dansejenisnya.berdasarkan Peraturan Daerah Kota Jambi Nomor 1 Tahun 2011 Tentang Pajak Daerah Pasal19.Subjek pajak hiburan adalah orang pribadi atau badan yang menikmatihiburan. wajib pajak hiburan adalah orang pribadi atau badan yang menyelenggarakanhiburan Dasar pengenaan pajak hiburan adalah jumlah uang yang diterima atau yang seharusnya diterima oleh penyelenggara hiburan.Jumlah uang yang seharusnya diterima oleh penyelenggara hiburan termasuk potongan harga dan tiket cuma-cuma yang diberikan kepada penerimaan jasa hiburan.tarif pajak untuk setiap jenis hiburan ditetapkan sebagai berikut:Pagelaran kesenian rakyat/tradisional, sebesar 5\% (lima persen) dari harga tandamasukPameran, pertunjukan, sirkus, akrobat, sulap, pertandingan olah raga, (termasuk yang diselenggarakan taman hiburan rakyat/tempat wisata air/waterpark/kolam renang) sebesar 20\% (dua puluh persen) dari harga tandamasukTontonan film, sebesar $20 \%$ (dua puluh persen) dari harga tanda masukPagelaran musik, tari, sebesar $25 \%$ (dua puluh lima persen) dari harga tandamasukPacuan kuda, kendaraan bermotor sebesar 30\% (tiga puluh persen) dari harga tandamasuk.

Tarif pajak untuk penyelenggaraan hiburan selain di atas, ditetapkan sebagaiberikut:Permainan ketangkasan (termasuk yang diselenggarakan game center), sebesar 30\% (tiga puluh persen) daripembayaranpanti pijat, releksi, permainan billyard, bolling, golf, sebesar 35\% (tiga puluh lima persen) daripembayaranMandi uap/spa, pusat kebugaran, pagelaran busana, kontes kecantikan, sebesar 30\% (tiga puluh persen) daripembayaranKaraoke, diskotik, klab malam, dan sejenisnya sebesar $40 \%$ (empat puluh persen) daripembayaran.Setiap penyelenggara hiburan pagelaran musik yang diselenggarakan di hotel atau tempat lainnya, wajib menyetorkan uangjaminan. uang jaminan adalah uang untuk pembayaran pajak hiburan yang akan diperhitungkan kembali setelah pagelaran berakhir sesuai dengan jumlah tiket atau tanda masuk yangterjual. besarnya uang jaminan ditetapkan dengan PeraturanWalikota.besaran pokok pajak hiburan yang terutang dihitung dengan cara mengalihkan tarif dengan dasar pengenaan pajak.Salah satu cara untuk mengukur kinerja adalah melihat efektivitas. Efektivitas lebih menunjukkan pada leberhasilan atau kegagalan dalam mencapai tujuan (Jones dan Pendiburg: 1996). Efektivitas berhubungan dengan derajat keberhasilan suatu operasi pada sektor public sehingga suatu kegiatan dikatakan efektif apabila kegiatan tersebut mempunyai pengaruh besar terhadap kemampuan menyediakan pelayanan masyarakat yang nerupakan sasaran yang telah di tetapkan sebelumnya (Munir : 2004).

Efektivitas merupakan ukuran berhasil tidaknya pencapaian tujuan unit kerja hal terpenting yang harus diperhatikan ialah efektivitas tidak menunjukkan tentang besar biaya yang dikeluarkan untuk mencapai tujuan tersebut, biaya bias saja melebihi jumlah yang sudah dianggarkan. Menurut Prawirosantoso (2000) mengatakan efektivitas adalah mengacu kepada ukuran keberhasilan pencapaian suatu tujuan atau apa yang dicapai dibandingkan apa yang direncanakan apabila konsep efektivitas dikaitkan pemungutan 
pajak daerah terhadap penerimaan pajak daera, maka efektivitas yang dimaksud adalah seberapa besar realisasi penerimaan pajak daerah berhasil mencapai tarhet yang seharusnya di capai pada periode tertentu.Salah satu cara untuk mengukur kinerja adalah melihat efektivitas. Efektivitas lebih menunjukkan pada leberhasilan atau kegagalan dalam mencapai tujuan (Jones dan Pendiburg: 1996). Efektivitas berhubungan dengan derajat keberhasilan suatu operasi pada sektor public sehingga suatu kegiatan dikatakan efektif apabila kegiatan tersebut mempunyai pengaruh besar terhadap kemampuan menyediakan pelayanan masyarakat yang nerupakan sasaran yang telah di tetapkan sebelumnya (Munir : 2004).

Menurut (Halim: 1997) pengertian efektivitas berhubungan dengan derajat keberhasilan suatu operasi pada sektor public sehingga suatu kegiatan dikatakan efektiv jika kegiatan tersebut mempunyai pengaruh besar terhadap kemampuan menyediakan pelayanan masyarakat yang merupakan sasaran yang telah ditetapkan.

Menurut (Mardiasmono: 2002), efektivitas adalah ukuran berhasil tidaknya pencapaian tujuan unit kerja. Hal terpenting yang perlu dicatat adalah efektivitas tidak menunjukkan tentang berapa besar biaya yang telah dikeluarkan untuk mencapai tujuan, biaya boleh jadi melebihi dari jumlah yang telah dianggarkan

Efektivitas menurut (Pasaribu : 2003) adalah ukuran keberhasilan atau kegagalan dari organisasi dalam mencapai suatu tujuan. Berdasarkan pengertian diatas, maka dapat ditarik kesimpulan bahwa efektivitas adalah suatu keadaan yang di kehendaki dengan maksud mengukur seberapa jauh keberhasilan atau kegagalan dalam mencapai tujuan yang hendak dicapai.

Efektivitas adalah suatu keadaan yang terjadi sebagai akar yang dikehendaki.Kalua seseorang melakukan sesuatu perbuatan dengan maksud tertentu yang dikehendakinya, maka orang itu dikatakan efektiv bila menimbulkan akibat atau mempunyai maksud sebagaimana yagng dikehendakinya.

Selanjutnya efektivitas harus dinilai atau tujuan yang bias dilaksanakan dan bukan atas konsep tujuan yang maksimum. Jadi efektivitas menurut ukuran seberapa jauh organisasi berhasil mencapai tujuan yang layak dicapai. Apabila konsep efektivitas dikaitkan dengan jumlah tabungan masayarakat Bank Jambi maka efektivitas yang dimaksud adalah seberapa besar realisasi penerimaan jumlah tabungan masyarakat nerhasil mencapai potensi yang seharusnya dicapai pada periode tertentu (Halim :1997).

Menurut Harun(2003) standar pengukuran efektif atau tidaknya suatu keuangan dapat diketahui sebagai berikut Sumber : Harun (2003)

Efektivitas memberikan kesesuiana antara masukan input dengan keluaran output. Dengan tujuan keluaran output mudah diukur, dan secara jelas dapat diketahui secara contoh, pengeluaran bagian produksi secara fisik mudah dihitung kualitasnya. Dengan demikian, mudah diadakan pengukuran efektivitas kegiatannya. Masukan (input) dan keluaran (output). Jumlah tabungan biasanya dapat dinyatakan dengansatuan uang disebut pendapatan. Jika fungsi pajak berjalan dengan lancer maka akan berpengaruh positif terhadap perekonomian

\section{METODE}

\section{Jenis dan sumber data}

Berdasarkan jenisnya data dibagi menjadi 2 yaitu data primer dan data sekunder. Data Primer adalah data yang diperoleh atau dikumpulkan oleh peneliti secara langsung dari sumber datanya, dimana teknik pengumpulan datanya adalah antara lain dengan observasi, wawancara, diskusi terfokus dan penyebaran kuisioner. Sedangkan data sekunder adalah data yang telah dikumpulkan oleh lembaga pengumpul data dan dipublikasikan kepada masyarakat pengguna data. Data yang digunakan dalam 
penelitian ini adalah data sekunder menurut kurun waktu. Data sekunder biasanya berwujud data dokumentasi atau data laporan yang telah tersedia

Data yang digunakan adalah dengan melihat PAD terkhususnya data pajak hiburan yang dapat diambil dari Dinas Pendapata Daerah (DISPENDA) Kota JambiTeknik pengumpulan data adalah teknik dokumentasi yaitu dengan cara mencari data yang telah ada di instansi terkait, yaitu Dinas Pendapatan Daerah Kota Jambi

pajak hiburan adalah nilai penerimaan pajak yang merupakan hasil pemungutan pajak Hiburan di Kota Jambi periode 2010-2016 yang diukur dalam juta rupiah

efektivitas penerimaan pajak hiburan adalah suatu keadaan yang di kehendaki dengan maksud mengukur seberapa jauh keberhasilan atau kegagalan dalam mencapai tujuan hendak tercapai dari tahun 2010-2016

\section{Analisis data}

Analisis data merupakan proses penyederhanaan data dalam bentuk yang lebih mudah dibaca dan diinterprestasikan. Metode yang dipilih untuk menganalis data harus sesuai dengan pola penelitian dan variabel yang akan diteliti.

\section{Efektivitas}

Efektivitas adalah kemampuan pemerintah daerah dalam merealisasikan pendapatan asli daerah yang direncanakan dibandingkan dengan target yang ditetapkan berdasarkan potensi riil daerah. Efektivitas terkait dengan hubungan antara hasil yang diharapkan dengan hasil yang sesungguhnya dicapai Efektivitas dapat dicari dengan rumus sebagai berikut :

$$
\text { Efektivitas }=\frac{\text { Realisasi Penerimaan Pajak Hiburan }}{\text { Target Pajak Hiburan }} \times 100
$$

\section{Efektivitas penerimaan pajak hiburan diKota Jambi Tahun 2010-2016}

Jumlah penerimaan yang berasal dari komponen-komponen pajak daerah salah satunya adalah pajak daerah sebenarnya bisa ditingkatkan lagi, dengan banyaknya potensi pajak daerah yang belum dipungut. Efektivitas kompenen-komponen penerimaan pajak daerah di Kota Jambi memberikan gambaran mengenai fakta realisasi penerimaan dengan target atau melebihi target bearti semakin efektif dan apabila kurang dari target atau jauh dari target bearti tidak efektif. Adapun efektvitas penerimaan pajak Hiburan di Kota Jambi dapat dilihat dari Tabel 1.

Pada Tabel 1 dapat dilihat dari beberapa kategori efektif dan sangat efektif pada kategori efektif yaitu tahun 2015 dan untuk sangat efektif yaitu pada tahun 2010,2011,2012,2013,2014 dan 2016. Efektivitas penerimaan pajak hiburan pada Kota Jambi dari tahun 2010 sampai 2016 pada tahun 2010 dapat dilihat efektivitas pajak hiburan di Kota Jambi sebesar 115,98\% yaitu sangat efektif sedangkan pada tahun 2011 tingkat efektifivitas nya adalah sebesar 110,22\% yaitu sangat efektif. Pada tahun 2012 efetivitas pajak hiburan di Kota Jambi sebesar 111,33\% yaitu sangat efektif. Pada tahun 2013 efektivitas pajak hiburan di Kota Jambi sebesar 107,97\% yaitu sangat efektif. Pada tahun 2014 efektivitas pajak hiburan di Kota Jambi sebesar 100,31\% yaitu sangat efektif sedangkan pada tahun 2015 efektivitas pajak hiburan di Kota Jambi sebesar 67,41\% yaitu efektif. Dan pada tahun 2016 efektivitas pajak hiburan di Kota Jambi sebesar $102,30 \%$ yaitu sangat efektif dengan rata-rata sebesar 105,07\%. Jadi bisa kita lihat bahwa tingkat efektivitas pajak hiburan di Kota Jambi dengan rata-rata 105,08\% termasuk dalam kategori sangat efektif walaupun tingkat persentasenya berfluktuasi atau tidak stabil. 
Tabel 1. Efektivitas penerimaan pajak hiburan Kota Jambi Tahun 2010-2016

\begin{tabular}{ccccc}
\hline \multirow{2}{*}{ Tahun } & \multicolumn{2}{c}{ Pajak Hiburan } & \multirow{2}{*}{ Efektivitas } & \multirow{2}{*}{ Kategori } \\
\cline { 2 - 3 } & Realisasi & Target & & \\
\hline 2010 & $1,961,166,908.00$ & $1,690,850,000.00$ & $115,98 \%$ & Sangat efektif \\
2011 & $2,274,433,085.00$ & $2,063,500,000.00$ & $110,22 \%$ & Sangat efektif \\
2012 & $3,785,885,060.00$ & $3,400,582,332.00$ & $111,33 \%$ & Sangat efektif \\
2013 & $4,168,528,889.00$ & $3,860,640,000.00$ & $107,97 \%$ & Sangat efektif \\
2014 & $5,065,708,092.00$ & $5,050,000,000.00$ & $100,31 \%$ & Sangat efektif \\
2015 & $6,119,125,119.00$ & $7,000,000,000.00$ & $87,41 \%$ & Efektif \\
2016 & $7,673,051,524.00$ & $7,500,000,000.00$ & $102,30 \%$ & Sangat efektif \\
\hline \multicolumn{5}{c}{$\mathbf{1 0 5 , 0 7 \%}$} \\
\hline Sumlah
\end{tabular}

Nilai efektivitas pajak hiburan di Kota Jambi yang masuk kategori sangat efektif (dominan) lantaran masih relatif rendahnya pendapatan target pajak Hiburan. Budget pajak hiburan di tetapkan berdasarkan peningkatan rata-rata realisasi pajak hiburan selama beberapa tahun terakhir yang menjadi kan realisasi penerimaanya senantiasa lebih tinggi. Untuk kedepannya diharapkan penetapan budget pajak hiburan di Kota Jambi harus memperbaiki potensi oajak hiburan yang ada, sehingga perhitungan target yang mencapai kepada pajak hiburan daerah akan menjadikan capaian output dari potensi pajak hiburan yang ada di harapkan lebih maksimal.

Pada Tabel 2 menunjukkan bahwa maka akan dijelaskan berapa besar kontribusi pajak Hiburan terhadap Pajak Daerah di Kota Jambi dan rata-rata kontribusi yang ada di Kota Jambi sebesar 4,56 persen. Selanjutnya pada Tabel 2 dapat dilihat perkembangan kontribusi pajak Hiburan yang ada di Kota Jambi terhadap pajak daerah Kota Jambi dalam periode 2010-2016. Pada tahun 2010 kontribusi yang diberikan pleh pajak hiburan kepada pajak Daerah Kota Jambi sebesar 5,51\% sedangkan pada tahun 2011 kontribusi yang diberikan oleh Pajak Hiburan kepada pajak daerah sebesar 3,18\% dan pada tahun 2012 pajak hiburan memberikan kontribusi kepada pajak daerah sebesar 5,16\% dan pada tahun 2013 pajak hiburan memberikan kontribusi kepada pajak daerah sebesar 4,55\% dan pada tahun 2014 pajak hiburan memberikan kontribusi kepada pajak daerah sebesar 3,93\% dan pada tahun 2015 mengalami perkembangan kontribusi kepada pajak daerah sebesar 4,13\% dan pada tahun 2016 pajak hiburan memberikan kontribusi kepada pajak daerah sebesar 4,83\% dengan rata-rata sebesar 4,65\%

Tabel 2. Penerimaan pajak hiburan terhadap pajak daerah Kota Jambi 2010-2016

\begin{tabular}{cccc}
\hline Tahun & Pajak Hiburan & Pajak Daerah & $\begin{array}{c}\text { Kontribusi } \\
(\boldsymbol{\%})\end{array}$ \\
\hline 2010 & Rp.1,961,166,908.00 & Rp.35,558,902,822.00 & 5,51 \\
2011 & Rp.2,274,433,085.00 & Rp.59,570,219,207.90 & 3,81 \\
2012 & Rp.3,785,885,060.00 & Rp.73,344,791,806.56 & 5,16 \\
2013 & Rp.4,168,528,889.00 & Rp.91,476,549,341.38 & 4,55 \\
2014 & Rp.5,065,708,092.00 & Rp.128,824,086,122.82 & 3,93 \\
2015 & Rp.6,119,125,119.00 & Rp.147,889,448,423.30 & 4,13 \\
2016 & Rp.7,673,051,524.00 & Rp.158,740,884,098.89 & 4,83 \\
\hline \multicolumn{4}{c}{ Rata-Rata } \\
\hline
\end{tabular}

Sumber: Dispenda Kota Jambi Tahun 2010-2016 ( diolah)

Kontribusi tertinggi diberikan pajak hiburan ini mengiindikasi bahwa sosialisasi terhadap masyarakat mengenai pajak cukup berhasil, meningkatnya konsumsi 
masyarakat terhadap hiburan ,bertambahnya wajib pajak, dan adanya tunggakan pajak yang dibayarkan pada tahun-tahun tersebut, sebaliknya kontribusi yang minim dapat disebabkan adanya oknum-oknum yang tidak tepat membayar pajak ,palitinya atau tutupnya bisnis usaha menjadikan berhentinya wajib pajak.

Tabel 3.Tingkat mengukur efektivitas pajak hiburan

\begin{tabular}{ll}
\hline Persentase & Kritertia \\
\hline$>100 \%$ & Sangat efektif \\
$81 \%-100 \%$ & Efektif \\
$61 \%-80 \%$ & Cukup efektif \\
$40 \%-60 \%$ & Tidak efektif \\
\hline
\end{tabular}

Sumber: Sidik (dikutip oleh Enggar, Sri Rahayu, dan Wahyudi, 2011(diolah)

\section{Kontribusi}

Kontribusi yang diberikan seseorang untuk meningkatkan efektivitas hidupnya. Hal ini dilakukan dengan cara menajamkan posisi perannya, sesuatu yang kemudian mejadi bidang spesialis, agar lebih tepat sesuai dengan kompetensi (Mourin. M. Mosal, 2013). Kontribusi Pemungutan Pajak Hiburan terhadap Pendapatan Asli Daerah dapat dihitung dengan rumus sebagai berikut:

\section{Kontribusi $=\frac{\text { Realisasi Pajak Hiburan }}{\text { Realisaisi PAD }} \times 100$}

\section{Implikasi kebijakan penelitian}

Berdarakan hasil penelitian menunjukkan bahwa perkembangan pajak hiburan di Kota Jambi terus mengalami perubahan setiap tahunnya. Tahun 2010 sebesar Rp.1.961.166.908,00 atau sebesar 6,14\% dari tahun sebelumnya perkembangan terkecil pada tahun 2011 Rp. 2.274.433.085.00 atau 6,14\% dan terbesar pada tahun $2012 \mathrm{Rp}$. 3.785.885.060,00 atau 66,45\% implikasi dari penelitian ini adalah perkembangan pajak hiburan di Kota Jambi periode 2010-2016 memiliki rata-rata perkembangan sebesar $25,065 \%$ dari setiap tahunnya. Pajak hiburan ini sebenarnya masih dapat di tingkatkan lagi dengan memberikan kegiatan-kegiatan bimbingan dan penyuluhan oleh pihak terkait kepada pemeilik atau pengelola tempat hiburan di Kota Jambi untuk aktif dalam melakukan pembayaran pajak dan lebih meningkatkan pelayanan.

Berdasarkan tingkat efektivitas dari pajak hiburan di Kota Jambi periode 20102016, maka didapat untuk tingkat efektivitas sangat efektif adalah pada tahun 2010 dengan tingkat koefesien sebesar 115,98\% dan terkecil pada tahun 2015 dengan tingkat koefesien sebesar 87,41\% serta rata-rata dari efektivitas dari tahun 2010-2016 adalah sebesar 105,08\%yang bearti tingkat efektivitas pajak hiburan ini sangat efektif. Hasil penelitian ini adalah pemerintah daerah harus merancang target untuk masing masing penerimaan pajak daerah berdasarkan potensi pajak daerah, sehingga bisamemberikan hasil yang optimal mengingat pentingnya kontribusi pajak hiburan terhadap pajak daerah bagi perkembangan ekonomi dalam menunjang pembangunan daerah, maka perlu peningkatan penerimaan daerah itu sendiri. Peningkatan penerimaan daerah pada umumnya dipengaruhi oleh peningkatan komponen pajak hiburan. Sehingga orientasinya perlu diciptakan kebijakan yang diharpkan dapat meningkatkan pendapatan Pajak daerah melalui peningkatan penerimaan pajak hiburan.

Jika Kota Jambi ingin mempertahankan bahkan meningkatkan penerimaan pajak daerah, maka Kota Jambi harus meningkatkan produktivitas baik objek pajak maupun subjek pajak. Sedangkan besar kecilnya kontribusi yang diberikan komponen pajak hiburan ini tidak terlepas dari kesadaran masyarakat dalam membayar pajak banyaknya 
sumber subjek dan objek pajak, tingginya kontribusi yang diberikan, maka otomatis proses pembangunan di Kota Jambi akan selalu meningkat khususnya untuk masyarakat terutama pada bidang sarana dan prasarana.

\section{HASIL DAN PEMBAHASAN}

\section{Perkembang efektifitas penerimaan pajak}

Jumlah penerimaan yang berasal dari komponen-komponen pajak daerah salah satunya adalah pajak daerah sebenarnya bisa ditingkatkan lagi, dengan banyaknya potensi pajak daerah yang belum dipungut. Efektivitas kompenen-komponen penerimaan pajak daerah di Kota Jambi memberikan gambaran mengenai fakta realisasi penerimaan dengan target atau melebihi target bearti semakin efektif dan apabila kurang dari target atau jauh dari target bearti tidak efektif.

Berdasarkan hasil penelitian menunjukkan bahwa perkembangan pajak hiburan di Kota Jambi terus mengalami perubahan setiap tahunnya. Tahun 2010 sebesar Rp.1.961.166.908,00 atau sebesar 6,14\% dari tahun sebelumnya perkembangan terkecil pada tahun 2011 Rp. 2.274.433.085.00 atau 6,14\% dan terbesar pada tahun 2012 Rp.3.785.885.060,00 atau 66,45\% implikasi dari penelitian ini adalah perkembangan pajak hiburan di Kota Jambi periode 2010-2016 memiliki rata-rata perkembangan sebesar 25,065\% dari setiap tahunnya. Pajak hiburan ini sebenarnya masih dapat di tingkatkan lagi dengan memberikan kegiatan-kegiatan bimbingan dan penyuluhan oleh pihak terkait kepada pemeilik atau pengelola tempat hiburan di Kota Jambi untuk aktif dalam melakukan pembayaran pajak dan lebih meningkatkan pelayanan.

Berdasarkan tingkat efektivitas dari pajak hiburan di Kota Jambi periode 20102016, maka didapat untuk tingkat efektivitas sangat efektif adalah pada tahun 2010 dengan tingkat koefesien sebesar 115,98\% dan terkecil pada tahun 2015 dengan tingkat koefesien sebesar 87,41\% serta rata-rata dari efektivitas dari tahun 2010-2016 adalah sebesar 105,08\%yang bearti tingkat efektivitas pajak hiburan ini sangat efektif. Hasil penelitian ini adalah pemerintah daerah harus merancang target untuk masing masing penerimaan pajak daerah berdasarkan potensi pajak daerah, sehingga bisa memberikan hasil yang optimal

Tabel 4. Penerimaan pajak hiburan terhadap pajak daerah Kota Jambi Tahun 2010-2016

\begin{tabular}{cccc}
\hline Tahun & Pajak Hiburan & Pajak Daerah & $\begin{array}{c}\text { Kontribusi } \\
(\%)\end{array}$ \\
\hline 2010 & Rp.1,961,166,908.00 & Rp. $35,558,902,822.00$ & 5,51 \\
2011 & Rp.2,274,433,085.00 & Rp.59,570,219,207.90 & 3,81 \\
2012 & Rp.3,785,885,060.00 & Rp.73,344,791,806.56 & 5,16 \\
2013 & Rp.4,168,528,889.00 & Rp.91,476,549,341.38 & 4,55 \\
2014 & Rp.5,065,708,092.00 & Rp.128,824,086,122.82 & 3,93 \\
2015 & Rp.6,119,125,119.00 & Rp.147,889,448,423.30 & 4,13 \\
2016 & Rp.7,673,051,524.00 & Rp.158,740,884,098.89 & 4,83 \\
\hline
\end{tabular}

Sumber: Dispenda Kota Jambi Tahun 2010-2016 (diolah)

Pada Tabel 4 dapat dilihat perkembangan kontribusi pajak Hiburan yang ada di Kota Jambi terhadap pajak daerah Kota Jambi dalam periode 2010-2016. Pada tahun 2010 kontribusi yang diberikan pleh pajak hiburan kepada pajak Daerah Kota Jambi sebesar 5,51\% sedangkan pada tahun 2011 kontribusi yang diberikan oleh Pajak Hiburan kepada pajak daerah sebesar 3,18\% dan pada tahun 2012 pajak hiburan memberikan kontribusi kepada pajak daerah sebesar 5,16\% dan pada tahun 2013 pajak hiburan memberikan kontribusi kepada pajak daerah sebesar 4,55\% dan pada tahun 
2014 pajak hiburan memberikan kontribusi kepada pajak daerah sebesar 3,93\% dan pada tahun 2015 mengalami perkembangan kontribusi kepada pajak daerah sebesar 4,13\% dan pada tahun 2016 pajak hiburan memberikan kontribusi kepada pajak daerah sebesar $4,83 \%$ dengan rata-rata sebesar $4,65 \%$

\section{KESIMPULAN DAN SARAN}

\section{Kesimpulan}

Berdasarkan analisis yang dilakukan terhadap perkembangan pajak hiburan di Kota Jambi memeiliki rata rata perkembangan peride 2010-2016 sebesar 25,065\%. terus mengalami perubahan naik turun setiap tahunnya. Perkermbangan tersebut masih kurang maksimal dan pasti masih bisa ditingkatkan lagi. Berdasarkan tingkat efektivitas dari pajak hiburan di Kota Jambi periode 2010-2016, maka didapat untuk ditingkatkan efektivitas paling besar adalah pada tahun 2010 dengan tingkat koefesien sebesar $115,98 \%$ serta rata-rata dari efektivitas dari tahun 2010-2016 adalah sebesar 105,08\% yang mengidentifikasikan efektivitas pajak hiburan di Kota Jambi dengan rata-rata sebesar 105,dalam membayar pajak yang telah ditetapkan. Hendaknya bagi instansi terkait yang bekerja dibidang pajak hiburan dan apapun yang menyangkut tentang pajak hiburan untuk perlu ditingkatkan lagi

\section{DAFTAR PUSTAKA}

Arikunto,Suharsimi(2002). Prosedur penelitian suatu pendekatan dan praktek edisi revisis kelima, Rineke Cipta :Jakarta

Anthony. (2004). Analisis proporsi penerimaan daerah terhadap produk domestik regional bruto (PDRB) Kota Jambi Periode 1992-2002.Skripsi FE UNJA : Jambi

Azhari. (2015). Perpajakan di Indonesia (Keuangan, pajak, Daerah di Kabupaten Kerinci, Skripsi FE.UNJA: Jambi

Halim.(1996).Pajak dan retribusi daerah, Erasm:Bandung

Mardiasmono.(2002). Perpajakan. Andi Offset: Yogyakarta

Mardiasmono (2009). Perpajakan (edisi revisi 2009).Andi Offset:Yogyakarta

Marihot P Siajaan. (2005). Pajak dan retribusi daerah, UPP AMP YKPN: Yogyakarta

Pudyamoko, Sri. (2000). Pengantar hukum pajak. Andi Offset:Yogyakarta

Pudyamoko,Sri.(2007). Penegakan dan perlindungan hukum dibidang pajak Salemba Empat :Jakarta

Rosneli.(2003). Analisis kontribusi retribusi pengelolaan dan pengusahaansarang burung walet terhadap retribusi daerah di Tanjung JabungBarat, Skripsi FE UNJA: Jambi

Soffyan Edward, (2001).Kontribusi retribusi rumah sakit terhadap pendapatanasli daerah di Kabupaten Batanghari. Skripsi FE UNJA : Jambi

Suparmoko,M.(1997). Keuangan negara (teori dan praktek), BPFE: Jakarta

Suparmoko M, (2002). Ekonomi publik (Untuk Keuangan dan PembangunanDaerah), Andi:Yogyakarta

BPS (2018).Jumlah penduduk Kota Jambi. Badam Pusat Statistik:Kota Jambi Dalam Angka. Provinsi Jambi : Jambi

BPRD (2017).Badan pengelolaan pajak dan retribusi daerah Kota Jambi: Jambi

M Ariansyah, A Amir, E Achmad.(2014).Tingkat ketergantungan fiskal dan hubungannya dengan pertumbuhan ekonomi di Kota Jambi, Jurnal Perspektif Pembiayaan dan Pembangunan Daerah, 1 (3), 159-159

Romiyati,I, Y Yulmardi, A Bhakti. (2019).Faktor-faktor yang mempengaruhi penerimaan retribusi daerah di Kota Jambi, Jurnal Paradigma Ekonomika 14 (2), 83-96 